\title{
KESIAPSIAGAAN MASYARAKAT DALAM MENGHADAPI BENCANA BANJIR DI DESA PENYABANGAN KECAMATAN GEROKGAK KABUPATEN BULELENG
}

\author{
Surya Darma Yudistira, Dw. Md Atmaja, I Wyn Krisna Eka Putra \\ Jurusan Pendidikan Geografi, Fakultas Hukum dan IImu Sosial \\ Universitas Pendidikan Ganesha \\ Singaraja, Indonesia \\ e-mail : suryadarmayudistira@gmail.com, atmajadewamade@yahoo.com, \\ krisna.ekaputra@yahoo.com
}

\begin{abstract}
Abstrak
Penelitian ini bertujuan untuk mengetahui pengetahuan, kesiapsiagaan masyarakat terkait bencana banjir serta untuk mengetahui hubungan antara pengetahuan dengan kesiapsiagaan masyarakat dalam menghadapi bencana banjir di Desa Penyabangan Kecamatan Gerokgak Kabupaten Buleleng. Penilitian ini menggunakan metode deskriptif kuantitatif, desain penelitian menggunakan rancangan korelasi bivariat dengan pendekatan ekologi. Populasi dalam penelitian ini adalah masyarakat yang mengalami dampak terparah bencana banjir di Desa Penyabangan dengan total jumlah kepala keluarga sebesar 167 jiwa. Penentuan jumlah sampel ditentukan dengan tabel Isaac dan Michael dengan tingkat kesalahan 5\% maka jumlah sampel sebanyak 128 responden. Data pengetahuan dan kesiapsiagaan masyarakat diperoleh dari hasil kuisioner yang telah disebar peneliti kepada kepala keluarga di Desa Penyabangan. Hasil penelitian menunjukkkan bahwa pengetahuan masyarakat terkait bencana banjir di Desa Penyabangan berada pada kategori menengah atas, sedangkan kesiapsiagaan masyarakat terkait bencana banjir berada pada kategori cukup/sedang. Berdasarkan hasil analisis korelasi dengan menggunakan rumus pearson product moment, terdapat hubungan yang signifikan antara pengetahuan dengan kesiapsiagaan masyarakat dalam menghadapi bencana banjir di Desa Penyabangan Kecamatan Gerokgak Kabupaten Buleleng.
\end{abstract}

Kata Kunci : Pengetahuan, Kesiapsiagaan, Bencana Banjir

\begin{abstract}
This study aims to determine knowledge, community preparedness related to flood disaster and to know the relationship between knowledge with community preparedness in the face of floods in the Village Penyabangan Gerokgak District Buleleng regency. This research uses quantitative descriptive method, research design using bivariate correlation design with ecological approach. The population in this study is the people who experienced the worst impact of floods in Penyabangan Village with a total head of household of 167 people. Determination of the number of samples determined by tables Isaac and Michael with error rate $5 \%$ then the number of samples as much as 128 respondents. Data of knowledge and community preparedness were obtained from questionnaires that have been disseminated by researcher to head of family in Penyabangan Village. The results showed that the knowledge of floodrelated communities in Penyabangan village was in the upper middle category, while the flood preparedness was in the moderate category. Based on the result of correlation analysis using pearson product moment formula, there is a significant correlation between knowledge with community preparedness in facing flood disaster in Penyabangan Village, Gerokgak Subdistrict, Buleleng Regency.
\end{abstract}


Keywords : Knowledge, Preparedness, Flood Disaster 